\title{
Compensation effect of winter snow on larch growth in Northeast China
}

\author{
Yuanqiao $\mathrm{Li}^{1,2} \cdot$ Xiuchen $\mathrm{Wu}^{1,2}$ (D) Yongmei Huang ${ }^{1,2} \cdot$ Xiaoyan $\mathrm{Li}^{1,2}$. \\ Fangzhong Shi ${ }^{1,2}$. Shoudong Zhao ${ }^{1,2} \cdot$ Yuting Yang ${ }^{3} \cdot$ Yuhong Tian $^{1,2} \cdot$ Pei Wang ${ }^{1,2}$. \\ Shulei Zhang ${ }^{1,2} \cdot$ Cicheng Zhang ${ }^{1,2} \cdot$ Yang Wang $^{1,2} \cdot$ Chongyang $\mathrm{Xu}^{4} \cdot$ Pengwu Zhao ${ }^{5}$
}

Received: 23 March 2020 / Accepted: 6 January 2021/Published online: 22February 2021

(C) The Author(s) 2021

\begin{abstract}
Winter snow plays a crucial role in regulating tree growth during the subsequent growing season in regions suffering seasonal or even annual drought stress, but the mechanisms of the potential compensation effect of winter snow on subsequent growing-season tree growth are not well understood. In this study, we establish tree-ring chronologies of six larch forest stands along a marked drought gradient across Northeast China. We identify the spatial pattern in the compensation effects of winter snow on subsequent growing-season tree radial growth and uncover a potentially enhanced compensation effect in drier climates. Our results indicate that in snow-rich sites, winter snow tends to exert a significantly positive effect on tree growth during the growing season, whereas this growth compensation effect is reduced in drier sites. More importantly, our findings identify a much higher compensation effect of winter snow on growing-season larch growth in drier years $(24.4-48.0 \%)$ than in wetter years $(6.1-8.1 \%)$ at snow-rich sites. Given the projected increase in both severity and duration of droughts in temperate regions, the potential compensation effect of winter snow could play a crucial role in mediating the adaptation ability of boreal/hemi-boreal forest ecosystems in response to a warmer and drier future climate in these regions.
\end{abstract}

Keywords Winter snow · Drought · Tree growth · Tree ring chronology · Compensation effect

Xiuchen $\mathrm{Wu}$

xiuchen.wu@bnu.edu.cn

1 Faculty of Geographical Science, Beijing Normal University, Beijing 100875, China

2 State Key Laboratory of Earth Surface Processes and Resource Ecology, Beijing Normal University, Beijing 100875, China

3 State Key Laboratory of Hydroscience and Engineering, Department of Hydraulic Engineering, Tsinghua University, Beijing 100084, China

4 College of Urban and Environmental Science, MOE Laboratory for Earth Surface Processes, Peking University, Beijing 100871, China

5 College of Forestry, Inner Mongolia Agricultural University, Hohhot 010020, China 


\section{Introduction}

Increase in both the frequency and severity of drought accompanying global warming has been widely observed and projected in temperate regions (IPCC 2013; Dai 2013). This has significant impacts on tree growth (Ciais et al. 2005; Fang and Zhang 2019; Trumbore et al. 2015; Vicente-Serrano et al. 2014). A widespread reduction in tree radial growth and increase in tree mortality triggered by warming-induced drought have been widely reported in many temperate forests (Allen et al. 2015; Allen et al. 2010; Liu et al. 2013) and have critical impacts on the regional water and carbon cycles, climate feedbacks, and human wellbeing (Dulamsuren et al. 2010; Dulamsuren et al. 2011; Rotenberg and Yakir 2010; Rotenberg and Yakir 2011; Trumbore et al. 2015; Anderegg et al. 2015). An increasing number of studies have been devoted to understanding spatio-temporal patterns in tree growth under drought conditions and the underlying physiological mechanisms of how trees cope with a drying climate (Allen et al. 2015; Allen et al. 2010; Huang et al. 2018; Rowland et al. 2015; Wu et al. 2012a; Wu et al. 2018b; Brodribb et al. 2020; Anderegg et al. 2020).

Winter snow emerges as an important driver of subsequent tree growth by regulating a range of ecosystem processes, yet these processes are often overlooked when considering the impacts of future climate on forest function. These processes include an increase in soil moisture content, which could partially compensate water loss caused by drought during the growing season (Potopova et al. 2016; Shamir et al. 2020), insulation effects of snow, which reduce winter damage to the shallow roots of trees (Blume-Werry et al. 2016; Reinmann and Templer 2016; Reinmann and Templer 2018; Wipf and Rixen 2010; Wipf et al. 2009; Reinmann et al. 2019), and regulation of the soil nutrient cycles (Wu 2018). The contributions of these different processes mediated by winter snow to tree growth are, however, heterogeneous among diverse bioclimatic regions. Increasing attention has been focused on the hydrothermal regulations of winter snow and its lagged effects on subsequent tree growth (Wang et al. 2018; Wu et al. 2018b; Zhang et al. 2017; Zhang et al. 2016a; Shamir et al. 2020), particularly in facing a warmer and drier climate regime in many temperate regions. Snow cover/depth acts as a uniquely sensitive climate variable in response to a rapidly changing climate, which depends on temperature and precipitation at a variety of temporal and spatial scales (Hamlet et al. 2005). Decreasing winter snowfall and earlier spring snowmelt in response to a near-surface warming and changing precipitation regime are seen over many parts of temperate mid-latitudes (Barnett et al. 2005). The response of tree growth to winter snow cover/depth could provide critical insight into the comprehensive and complex effects of winter climate on tree radial growth, particularly over cool temperate forests where tree growth tends to be susceptible to seasonal drought, and winter snow exhibits dramatic interannual variations.

Soil water replenishment from winter snowmelt may exert positive effects on subsequent growing-season tree growth, although the effects of winter snow on tree growth are dependent on the background climate condition (e.g., snow depth and monsoon regime) and local edaphic properties (Shamir et al. 2020; Mcllroy and Shinneman 2020). In temperate regions dominated by a monsoon climate, summer precipitation is the main water source for tree growth, but the enhanced demand for evapotranspiration linked to higher temperatures in this season may lead to intensified drought stress (Grossiord et al. 2020). In this context, winter snowfall may play a critical role in subsequent tree growth (Zhang et al. 2018). In particular, there is increasing evidence that tree growth in temperate regions responds to drought indices at longer time scales than in other ecoregions (Vicente-Serrano et al. 2014), which further confirms and highlights the potentially crucial legacy effects of winter snow on subsequent tree growth. 
Despite improved understanding of tree growth responses to variations in growing-season climate, little is known regarding how and to what extent winter snow will compensate for the subsequent growing-season tree growth in diverse bioclimatic regions already suffering or prone to seasonal drought stress (Ladwig et al. 2016; Zhang et al. 2018; Shamir et al. 2020; Davis and Gedalof 2018; Pederson et al. 2011). It is likely that these mechanisms balance out differently for different species and microsite environmental conditions. Preceding winter and spring precipitation play a critical role in temperate environments under dry climates (Kunz et al. 2018; Liu et al. 2013; Martin et al. 2018; Zhang et al. 2019b). However, we still lack information on the role of winter snow to store such precipitation for subsequent tree growth. Despite recent studies that found no marked compensatory effect of winter snow at regional scale across temperate China (Peng et al. 2010; Wu et al. 2019), a full picture of the potential compensation effect of winter snow on tree growth across diverse bioclimatic zones still remains elusive. One critical issue is how the compensation effect of winter snow varies along a drought gradient in semi-arid and sub-humid regions and what underlying processes drive the potential spatial divergence in such a compensation effect. We expect that the compensation effect of winter snow on tree radial growth would be more prominent under drier climate conditions.

In this study, we investigated the potentially divergent compensation effect of winter snow on subsequent tree growth along a drought gradient over Northeast China. Specifically, our main objectives were (1) to identify the spatial pattern in the relationship between winter snow depth and tree growth along a drought and snowfall gradient and (2) to evaluate the compensation effect of winter snow on tree growth between years with drier and wetter conditions. We hypothesized a significant compensation effect of winter snow on tree radial growth, particularly in sites with deeper snow depth, and under drier climate conditions due to the lower summer water supply. Our study adds to the understanding on how larch forests can cope with a warmer and drier future climate in regions with seasonal snow cover and intensified seasonal drought.

\section{Materials and methods}

\subsection{Study area and sample collection}

This study was conducted along a southwest-northeast transect (ranging from 41 to $52^{\circ} \mathrm{N}$ and 117 to $123^{\circ} \mathrm{E}$ ) in Northeast China (Fig. 1). The climate of this region is dominated by the East Asian monsoon system, with dry and cold winters and wet and warm summers. The annual mean temperature in the study region ranges from -4.5 to $5.6{ }^{\circ} \mathrm{C}$ (from northeast to southwest). Annual total precipitation ranges from 452 to $331 \mathrm{~mm}$, with more than $60 \%$ precipitation falling between June and September. Mean temperatures in January can be as low as -29.1 to $-13.4{ }^{\circ} \mathrm{C}$, while mean temperatures in July can reach 16.7 to $22.7^{\circ} \mathrm{C}$. In snowrich sites, multi-year mean snow depth can reach $13.9 \mathrm{~cm}$, while it was only $2.1 \mathrm{~cm}$ on average in snow poor sites during the period of 1960-2015. The snow cover period starts in October of the previous year and ends in April of the current year. In winter, seasonal frozen soil exists in our study region. The maximum depth of the seasonal frozen soil is approximately $1.8 \mathrm{~m}$ and depends on soil surface properties (soil moisture and organic layer) and plant community (Jin et al. 2007).

Larix gmelinii and Larix principis-rupprechtii are the two dominant tree species at our sampling sites. Both larch species are widely distributed over Northeast China. Six tree-ring 


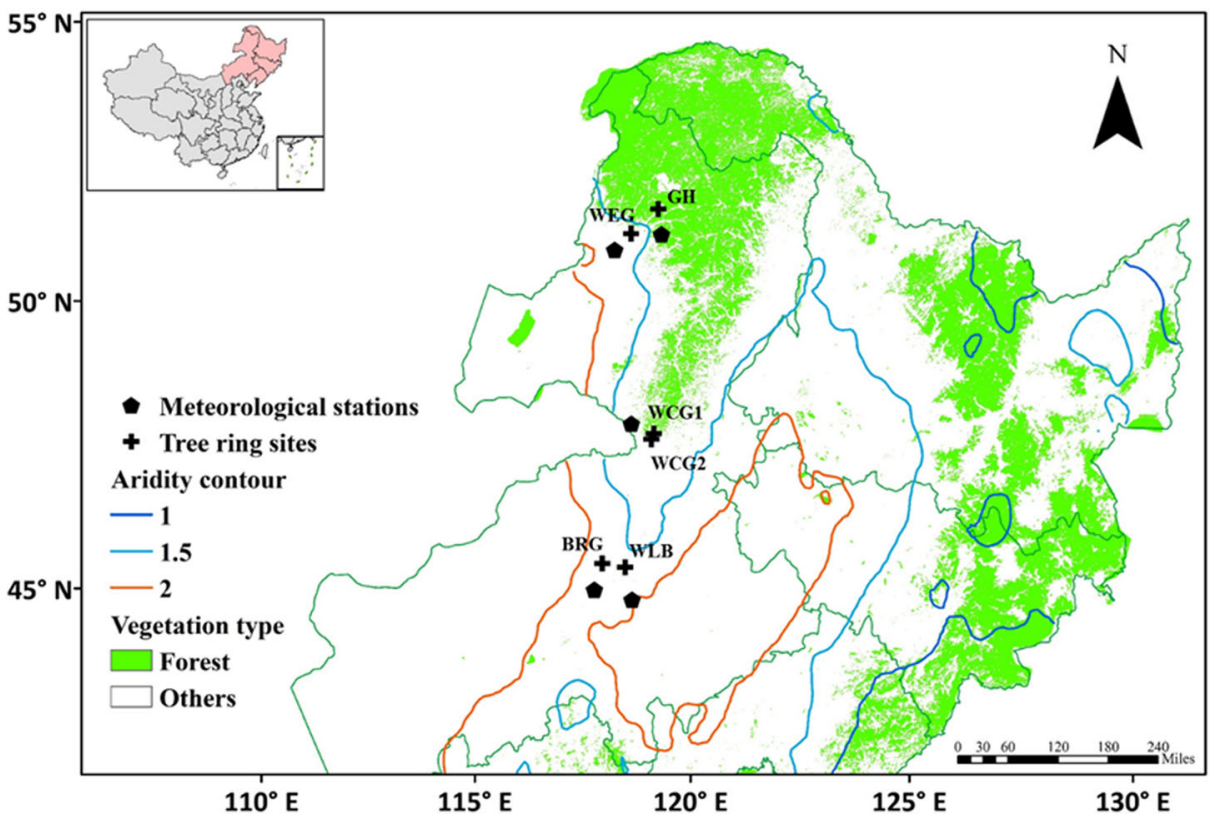

Fig. 1 Geographical location of our study sites in Northeast China. The black crosses represent the six sampling sites, and the black pentagons are the nearest climate stations. The contours of aridity index (the ratio of annual potential evapotranspiration to annual precipitation) shown here were estimated by the multi-year mean aridity index during 1951-2015

sampling sites were selected along a climate gradient in our study region (Fig. 1 and Table 1). The six study sites are consistently covered with plantation forests. These plantation forests consist of a simple stand structure with almost no understory trees. At each site, a square plot $(25 \mathrm{~m} \times 25 \mathrm{~m})$ was established, carefully controlling the slope, aspect, and soil properties (soil thickness and soil texture, etc.) to keep terrain and edaphic conditions as similar as possible among study sites. In each plot, we cored and measured all living canopy trees with diameter at breast height $(\mathrm{DBH})>5 \mathrm{~cm}$. Two perpendicular cores were collected per tree, through the pith of the tree or as close as possible to the pith. At least 30 trees were sampled in each plot.

All tree cores were sequentially mounted, sanded, visually cross-dated, and measured using the LINTAB system with precision to the nearest $0.001 \mathrm{~mm}$ (LINTAB ${ }^{\mathrm{TM}} 6$; Rinntech). Cores

Table 1 Basic information for the six tree-ring chronologies

\begin{tabular}{|c|c|c|c|c|c|c|c|}
\hline Sites & Species & $\begin{array}{l}\text { Elevation } \\
(\mathrm{m})\end{array}$ & $\begin{array}{l}\text { Longitude } \\
\text { (E) }\end{array}$ & $\begin{array}{l}\text { Latitude } \\
\text { (N) }\end{array}$ & $\begin{array}{l}\text { Tree } \\
\text { height }(\mathrm{m})\end{array}$ & $\mathrm{DBH}(\mathrm{cm})^{*}$ & $\begin{array}{l}\text { Canopy } \\
\text { cover } \\
(\%)\end{array}$ \\
\hline WLB & $\begin{array}{l}\text { Larix } \\
\quad \text { principis-rupprechtii }\end{array}$ & 973 & 119.18 & 44.09 & $12.18 \pm 1.35$ & $22.60 \pm 4.62$ & 28 \\
\hline BRG & $\begin{array}{l}\text { Larix } \\
\quad \text { principis-rupprechtii }\end{array}$ & 1154 & 118.64 & 44.78 & $9.37 \pm 1.34$ & $18.52 \pm 5.13$ & 50 \\
\hline WCG1 & Larix gmelinii & 850 & 120.30 & 46.78 & $8.99 \pm 1.23$ & $19.54 \pm 3.45$ & 40 \\
\hline WCG2 & Larix gmelinii & 900 & 120.38 & 46.87 & $9.90 \pm 1.31$ & $24.30 \pm 5.73$ & 35 \\
\hline WEG & Larix gmelinii & 620 & 120.61 & 50.39 & $9.88 \pm 1.05$ & $17.67 \pm 3.64$ & 40 \\
\hline $\mathrm{GH}$ & Larix gmelinii & 714 & 121.43 & 50.74 & $14.53 \pm 1.01$ & $27.45 \pm 4.39$ & 35 \\
\hline
\end{tabular}

* $\mathrm{DBH}$ diameter at breast height. Tree height and $\mathrm{DBH}$ are shown here in mean \pm standard deviations 
containing cross-dating errors were identified through COFECHA (Holmes 1983) and were corrected with the master chronology moduale of COFECHA. Cores that were too short, with too many cross-dating errors or with rotten piths were discarded. Then, ARSTAN program was applied to construct the individual tree-ring index chronology (http://www.ltrr.arizona. edu/software.html), using a detrending method of a spline function with a $50 \%$ frequency response of 32 years to remove biological growth trends as well as other low-frequency variations due to stand dynamics (Cook and Kairiukstis 1990). The basic statistics for these six tree-ring chronologies are listed in Table 2. The expressed population signal (EPS), a measure of chronology reliability, was calculated. An EPS above 0.85 was set to identify reliable time periods for each chronology suitable for the study of tree growth-climate relationships (Table 2).

\subsection{Climate data}

Daily climate data of air temperature, precipitation, and snow depth for the five climate stations surrounding our sampling sites (Fig. 1) during 1961-2015 were obtained from the China Meteorological Administration (Table S1). The self-calibrating Palmer Drought Severity Index (scPDSI) (van der Schrier et al. 2013) was used to evaluate the drought condition for our sampling sites. The gridded monthly scPDSI with a spatial resolution of $0.5^{\circ} \times 0.5^{\circ}$ for $1961-$ 2015 was obtained from the Climate Research Unit (https://crudata.uea.ac.uk/cru/data/ drought/) (Fig. S1). The scPDSI index represents soil moisture conditions after considering atmospheric input and soil evaporation (Wells et al. 2004). The frozen-ground period from approximately mid-October of the previous year to early April of the current year is regarded as the non-growing season in our study region. We calculated the annual mean value of scPDSI from October of the previous year to September of the current year to characterize the interannual drought conditions.

\subsection{Stable isotope analysis}

In April, July, and September of 2018, we collected soil samples and tree xylem samples for stable isotope analyses in three sites (WLB, WCG, and GH; Fig.1). At each site, five healthy larch trees were chosen, with similar ages $(30 \pm 3 \mathrm{yr})$, diameters $(22 \pm 3 \mathrm{~cm})$, and tree heights $(12 \pm 2 \mathrm{~m})$. For each tree individual, three $5 \mathrm{~cm}$-long twigs from the sun-exposed crown were obtained. For each twig, the phloem tissue was removed to avoid contamination by isotopic enriched water. Soil samples near the chosen trees were collected at depths of 10, 20, 40, 60, and $80 \mathrm{~cm}$. The soil depth at our study sites is generally not more than $80 \mathrm{~cm}$, overlying the

Table 2 Descriptive statistics for the six tree-ring chronologies

\begin{tabular}{lllllll}
\hline Sites & Time span & No. cores/trees & MS* & SD & PC1 & EPS $>0.85$ \\
\hline WLB & $1978-2015$ & $69 / 36$ & 0.29 & 0.35 & 0.45 & $1981-2015$ \\
BRG & $1983-2015$ & $86 / 45$ & 0.39 & 0.38 & 0.55 & $1985-2015$ \\
WCG1 & $1980-2015$ & $65 / 35$ & 0.41 & 0.37 & 0.54 & $1981-2015$ \\
WCG2 & $1962-2015$ & $51 / 28$ & 0.30 & 0.33 & 0.48 & $1964-2015$ \\
WEG & $1983-2015$ & $80 / 42$ & 0.13 & 0.09 & 0.64 & $1984-2015$ \\
GH & $1958-2015$ & $73 / 39$ & 0.21 & 0.28 & 0.70 & $1959-2015$ \\
\hline
\end{tabular}

$M S$ mean sensitivity, $S D$ standard deviation, $P C 1$ the variance expressed by the first principal component, EPS expressed population signal 
fractured parent material, so groundwater is not a potential water source. Thus, soil water from different layers was regarded as the main potential sources for tree water uptake. To prevent the effect of evaporation on isotopic contents, all soil and plant samples were stored in a refrigerator $\left(-4{ }^{\circ} \mathrm{C}\right)$ until the water was extracted using cryogenic vacuum distillation. Water in the soil and tree stems was extracted by a cryogenic vacuum distillation system (West et al. 2006). The hydrogen and oxygen isotopic compositions ( $\delta \mathrm{D}$ and $\delta^{18} \mathrm{O}$ ) of all samples were measured by the off-axis integrated cavity output spectroscopy method (Model DLT-100, Los Gatos Research, San Jose, CA, USA).

The most likely proportion of potential water sources used by trees was estimated by the Bayesian isotope mixing model MixSIAR (version 3.1.7) (http://conserver.iugo-cafe. org/user/brice.semmens/MixSIAR.MixSIAR) (Rothfuss and Javaux 2017). The isotopic signatures of larch xylem water and the mean and standard deviation of soil water in the five layers were input into the MixSIAR model as 'consumer' and 'source' data, that is, we considered five different sources of soil water. The discrimination data were set to zero for both $\delta^{18} \mathrm{O}$ and $\delta \mathrm{D}$ because isotopic fractionation does not occur during plant water uptake (Ehleringer and Dawson 1992). Individual effects as a random occurrence were included in all analyses. The run length of the Markov chain Monte Carlo was set to 'long' (chain length $=300,000$, burn $=200,000$, thin $=100$, and chains $=3$ ). The error option 'residual only' was specified in the model. We set "uninformative prior" in the model. The convergence of all the variables was assessed with the Gelman-Rubin and Geweke diagnostic tests (Wu et al. 2018a).

\subsection{Statistical methods}

Principal component analysis was performed to estimate the regional tree growth pattern as depicted by the first principal component (PC1) during 1983-2015. Partial least square regression was applied to quantify the relationships between standard tree-ring chronologies and different climate variables. Five types of climate factors were considered to investigate the growth-climate relationship: pre-growing-season temperature (PGT), growing-season temperature (GT), spring precipitation (SP), growing-season precipitation (GP), and mean winter snow depth (SD). Pre-growing-season, growing-season, spring, and winter were defined as previous October to current April, current May to Sep, MarchApril, and previous December to current February, respectively. A generalized linear model (GLM) was applied to analyze the relative contribution of different climate factors to variance in tree-ring chronologies. GLM is a regression approach commonly used to evaluate the relationship between dependent variables and multiple independent variables from a variety of statistical distributions with the link function. The link function estimates the relative contribution of each independent variable by means of variance decomposition and has been proven to be an effective tool in disentangling the relative contribution of different explanatory variables (Lopatin et al. 2016; Mccullagh 1984). The compensation effect of winter snow was evaluated by the contribution of winter snow to the variance of growing-season tree growth. Additionally, the potential compensation effects of winter snow on subsequent tree growth between dry and wet years were investigated and compared. Years with scPDSI values above and below the multi-year mean $\pm 1-$ standard deviation are defined as wet and dry years in this study, respectively.

Snow water equivalent (SWE) is the product of snow depth (SD) and snow density $\left(\rho_{\text {snow }}\right)$ and represents the resulting water column should a snowpack melt in place. The conversion 
between snow depth and snow water equivalent generally calculated using the following formula:

$$
\mathrm{SWE}=\mathrm{SD} \times \rho_{\text {snow }}
$$

There shows strong heterogeneity of snow density at large spatial scales; however, the spatially detailed information for snow density is hard to obtain. We thus used a fixed snow density $\left(0.24 \mathrm{~g} / \mathrm{cm}^{3}\right)$ to convert snow depth to snow water equivalent (Takala et al. 2011). The proportion of winter snow water equivalent to pre-growing-season precipitation was calculated.

\section{Results}

\subsection{Temporal trends in tree growth and climate}

Linear regression analyses showed that the annual mean scPDSI at our study sites all exhibited a significantly decreasing trend in the period of 1980-2015, with rates of decrease ranging from 0.19 to 0.24 /decade, despite great interannual variations (Fig. S1). Mean growing-season temperatures exhibited significantly increasing trends at our study sites, whereas neither spring precipitation nor growing-season precipitation showed significant trends in the period of 1980-2015. Mean winter snow depth showed divergent trends in our sampling transect, with an increasing trend in the climate stations surrounding the snow rich sites, but a slightly decreasing trend in the stations surrounding the two snow poor sites (i.e., WLB and BRG) in the period of 1980-2015 (Fig. S1, Table S1).

The six standard tree-ring chronologies are shown in Fig. 2. The correlation coefficients between each tree chronology and the master chronology were consistently above 0.6, indicating a strong shared signal in the interannual variations among trees in each sampling site (Table S2). The interannual variations, represented by the coefficient of variance, of the six tree-ring chronologies consistently exhibit an increasing trend, evidenced by the sliding analysis with a moving window length of 5 years (Fig. S2 a-f).

The first and second PCs (PC1 and PC2) of the six tree-ring chronologies accounted for $54.0 \%$ and $18.5 \%$ of the total variance, respectively. Although the six tree-ring chronologies were associated with different loadings for PC1, all chronologies were positively correlated with $\mathrm{PC}$, indicating that they shared a common variance. This finding illustrates that the six tree-ring chronologies shared similar growth patterns at the regional level. Tree-ring chronologies at the two drier sites (WLB and BRG) were mainly negatively correlated with PC2, while tree-ring chronologies of the other sites all had a positive correlation with PC2 (Fig. S3). We then used PC1 to depict regional tree growth. Correlation analyses between PC1 and monthly scPDSI in the period of 1983-2015 showed that scPDSI was significantly and positively correlated with regional tree growth during all months, which demonstrates that regional tree growth across our study transect in Northeast China is strongly limited by drought stress (Fig. S3).

\subsection{Response of tree growth to different climate factors}

GLM analyses showed that tree growth of Larix principis-rupprechtii responded significantly and positively to spring precipitation (Fig. 3a) at the snow poor site of WLB, with a relative 

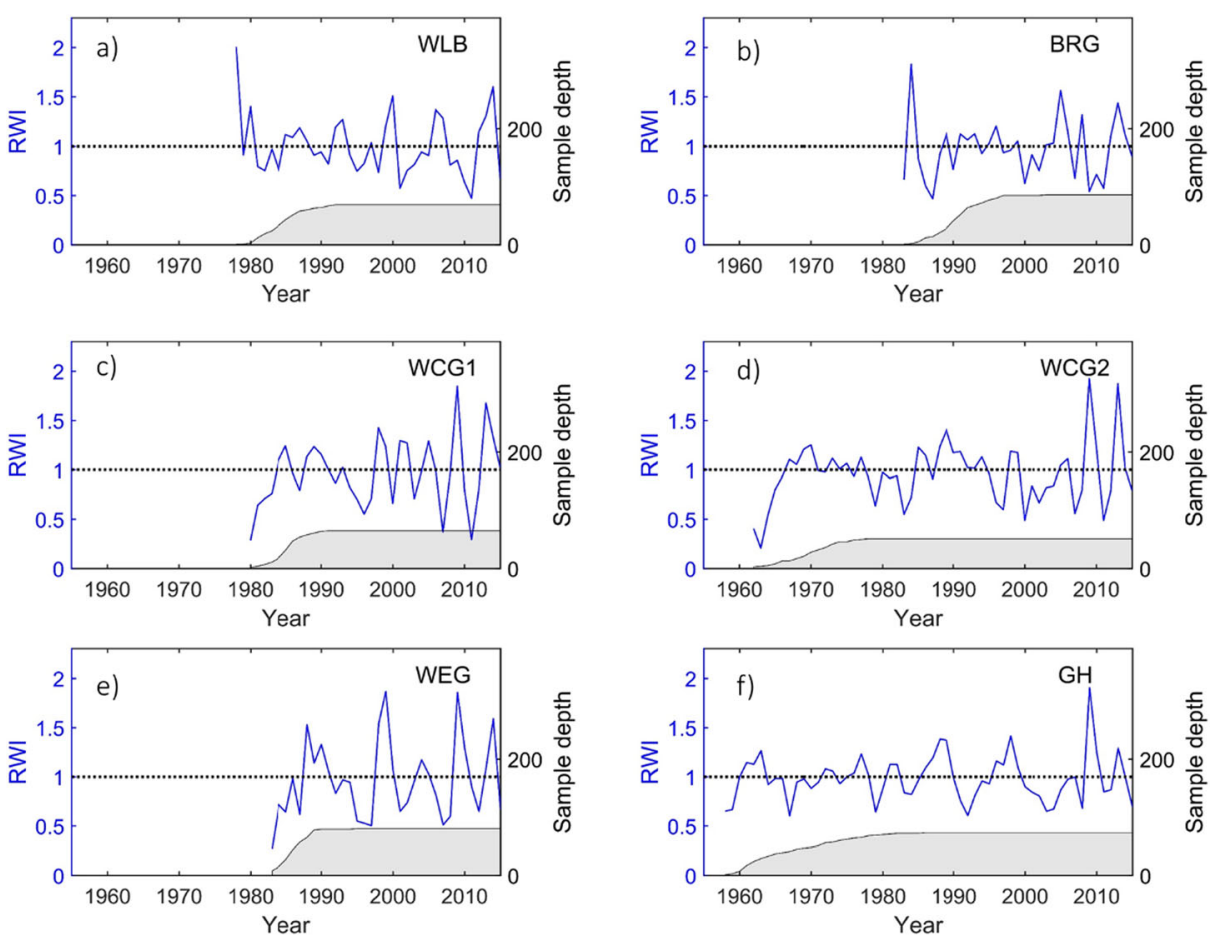

Fig. 2 Standard tree-ring chronologies (blue lines) for Larix principis-rupprechtii in WLB and BRG (a, b), and Larix gmelinii in WCG1 and WCG2 (c, d), and WEG and GH (e, f). Gray shade in (a-f) shows the sample depth

contribution of $9.1 \%$ to tree growth. Tree growth of Larix gmelinii in the middle part (i.e., WCG1 and WCG2) of our transect exhibited significantly negative and positive responses to mean growing-season temperature and spring precipitation, respectively (Fig. S4c, d). The mean growing-season temperature and spring precipitation contributed $7.1 \%$ and $21.1 \%$ to the variance of tree growth at site WCG1, with corresponding values of $7.3 \%$ and $23.1 \%$ for site WCG2, respectively. Winter snow did not contribute to regulating tree growth in these two sites (Fig. 3c and d). In contrast, at the two snow-rich sites (WEG and GH), with deeper (13.6 and $13.9 \mathrm{~cm}$ ) winter snow accumulation and a higher proportion $(12.0 \%$ and $11.0 \%)$ of winter snow water equivalent to pre-growing-season precipitation (Fig. S5), tree growth of Larix gmelinii responded positively to mean winter snow depth $(p=0.05$ in WEG and $p=0.1$ in $\mathrm{GH})$. Mean winter snow depth contributed $12.2 \%$ and $9.8 \%$ to the variance in tree growth at WEG and GH, respectively (Fig. 3e and f). Except for the winter snow depth, tree growth of Larix gmelinii at these two sites did not show significant relationships to any other climate factors (Fig. 3e and $\mathrm{f}$ ).

\subsection{Compensation effect of winter snow for tree growth}

To further investigate the potential compensation effect of winter snow on the subsequent growing-season tree growth under drier conditions, we compared the relative contributions of winter snow depth and other climate factors to larch growth in dry and wet years at the six sites (Table S3, Fig. 4). The relative contribution of spring precipitation at snow poor sites (i.e., WLB and BRG) was significantly higher in dry years $(37.7 \%$ and $71.4 \%)$ than in wet years 

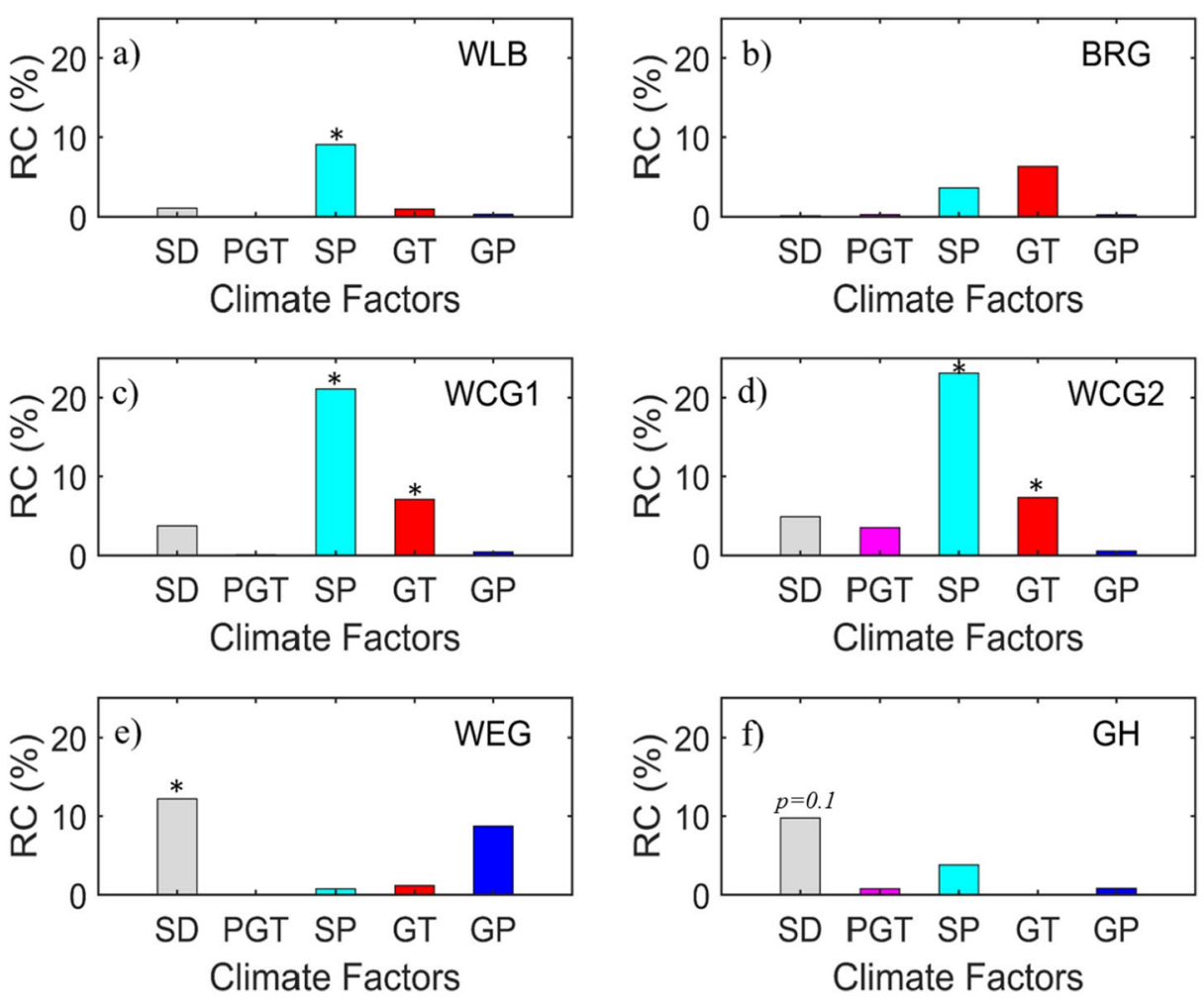

Fig. 3 Relative contribution ( $\mathrm{RC}, \%)$ of different climate factors to variations in tree growth in six sites (a-f). Bars represent the relative contribution of winter snow depth (SD), pre-growing-season temperature (PGT), spring precipitation (SP), growing-season precipitation (GP), and mean growing-season temperature (GT) to variance in six tree-ring chronologies during 1983-2015. Stars indicate statistically significant $\operatorname{RC}(p<0.05)$

(3.4\% and 36.6\%) (Fig. 4a and b). Tree growth in the middle part of our transect was more limited by the mean growing-season temperature in dry years, accompanied by an increased positive effect of spring precipitation (Fig. 4c and d). More interestingly, at snow-rich sites (i.e., WEG and $\mathrm{GH}$ ), a higher compensation effect of winter snow depth on growing-season tree growth was observed in dry years (24.4-48.0\%) than wet years (6.1-8.1\%) (Fig. 4e and f).

\subsection{Seasonal water use strategy}

During April and July, the larch trees in our study region mainly uptake soil water from the 0-20-cm soil layer, with the proportion ranging from 62.8 in dry sites (i.e., WLB) to $75.3 \%$ in wet sites (i.e., GH) (Fig. 5). However, the proportion of water uptake from the topsoil (i.e., $0-10 \mathrm{~cm}$ ) in early and mid-growing-season is much smaller in dry $(44.6 \%)$ than in wet sites (69.4\%). Interestingly, in September, the water uptake from shallow layers decreases dramatically compared to the uptake in early and mid-growing-season. Instead, the larch trees generally uptake soil water from much deeper soil layers (i.e., below $20 \mathrm{~cm}$ ) in September. Our findings show a clear shift in the water uptake regime from early and mid-growing-season to late growing-season, despite the site-to-site difference in either of the two periods. 

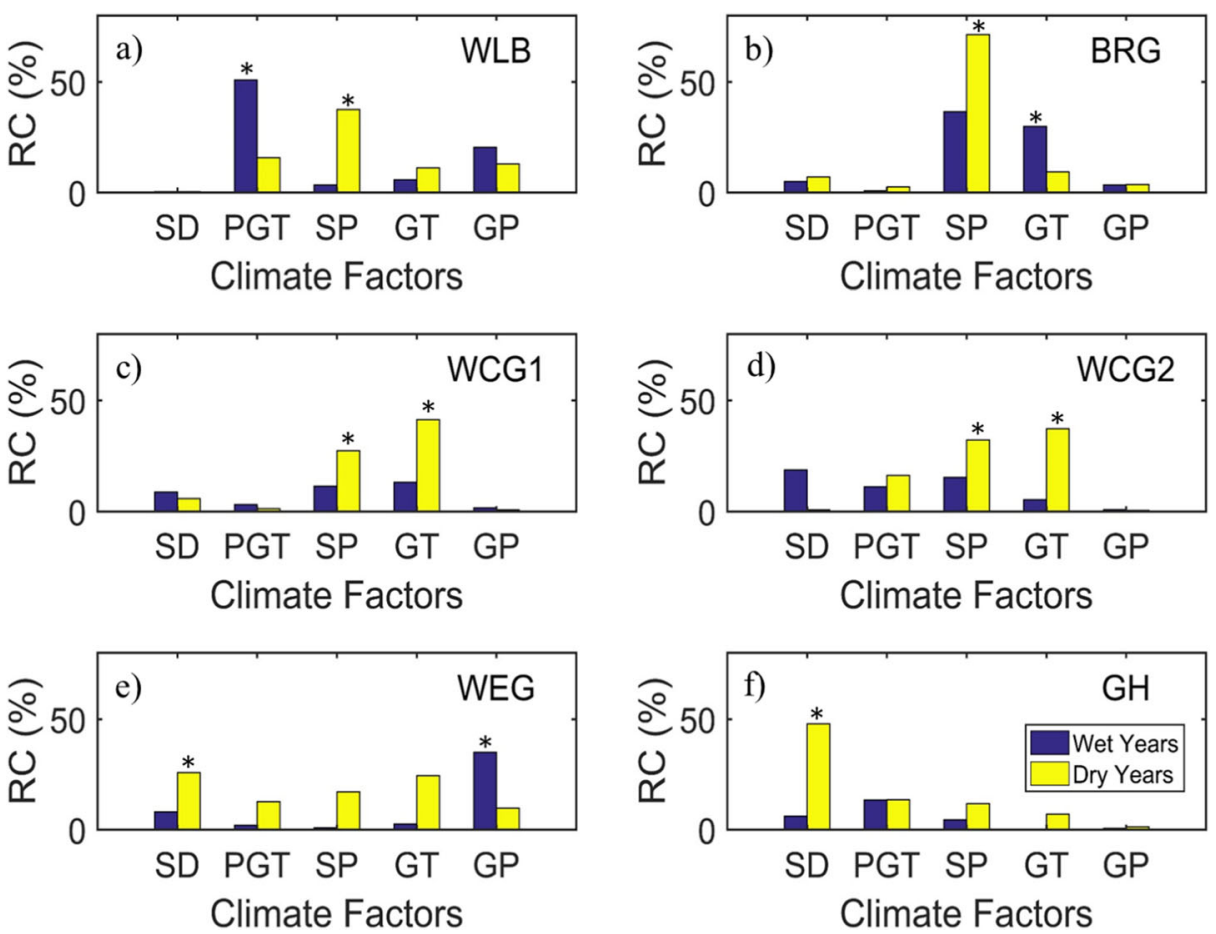

Fig. 4 Comparison of the relative contribution $(\mathrm{RC}, \%)$ of different climate factors to tree growth in dry years (yellow bars) and wet years (blue bars). Bars show the relative contribution of winter snow depth (SD), pregrowing-season temperature (PGT), spring precipitation (SP), growing-season precipitation (GP), and mean growing-season temperature (GT) to variance in six tree-ring chronologies during 1983-2015. Asterisks indicate statistically significant at $95 \%$ confidence level $(p<0.05)$

\section{Discussion}

\subsection{Vulnerability of tree growth to drought}

Our findings along a drought gradient clearly indicate that larch forests in this region are suffering from severe drought stress, as evidenced by the significantly positive response of regional tree growth to scPDSI in all months. More importantly, we revealed that the interannual variations in tree-ring chronologies across all sites are consistently increasing with time during our study period, implying that tree growth in our study region is becoming more variable with the rapidly changing climate, particularly the intensifying drought (Lyu et al. 2017; Shen et al. 2016; Shi et al. 2019; Zhang et al. 2016b; Zhu et al. 2018; Wu et al. 2018b). Regional tree growth shows negative and positive correlations with mean growing-season temperature and growing-season precipitation, respectively (Figs. S3 c and S4 c, d). This implies that warming-induced drought may have detrimental effects on tree growth (Pederson et al. 2012), although the tree-ring series did not present significant growth decline due to warming-induced water deficit, unlike that reported in previous studies over Northeast China (Wang et al. 2017; Zhu et al. 2018).

Tree growth of larch forests in Northeast China is susceptible to variations in spring precipitation and winter snow depth. Studies consistently report an increasingly critical role of preceding-season water supply to the subsequent growing-season tree growth and 

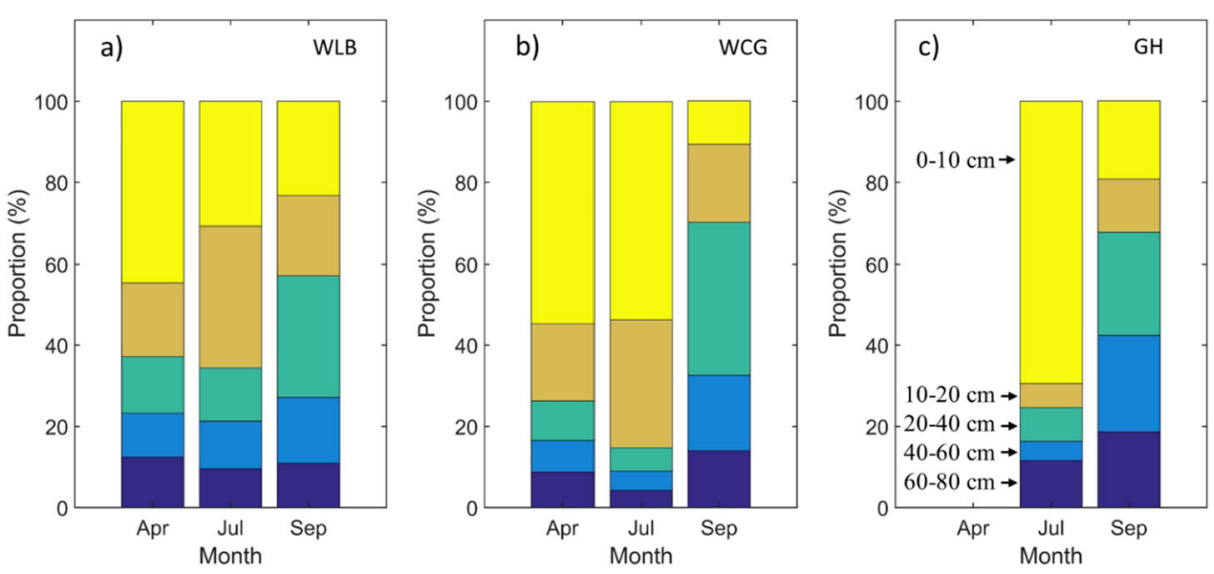

Fig. 5 Seasonal variations in water use sources from different soil layers for larch trees at study sites of WLB, WCG, and GH

xylogenesis in diverse temperate regions (Ren et al. 2018; Ren et al. 2015; Shamir et al. 2020). The onset of xylogenesis in drought stressed temperate forest was clearly triggered by a threshold-based precipitation accumulation, and spring precipitation affects the formation of the first row of early-wood vessels in water-limited forests (Zhang et al. 2019b). Snowmelt is also an important water resource for tree growth during the early growing season in boreal forests (Grippa et al. 2005; Zhang et al. 2018). Earlywood development was correlated with snowmelt in the previous year (Shamir et al. 2020). The response of tree growth to climate factors could also be regulated by other processes (Chakraborty et al. 2019; Rehschuh et al. 2017), including forest structure, soil properties, and local micro-climate.

Theoretically, tree growth can to some extent cope with intensified drought via various physiological mechanisms. First, trees can shift their behaviors in terms of coupling of water and carbon processes, including reducing shoot water potential and opening of the stomata and increasing water use efficiency (Trahan and Schubert 2016; Bhusal et al. 2020). Second, trees can adapt their water use strategy to seasonal changes in plant water supply, as evidenced by a clear shift in water uptake from shallow soil layers in early growing-season to deeper soil layers in late growing-season in our study (Fig. 5). The adaptive seasonal shift in water use of forests can partly compensate for low water availability in shallow layers by accessing deep water, potentially mitigating their vulnerability to summer drought (Ellsworth and Sternberg 2015; Allen et al. 2019), although the seasonal water use strategy might be species dependent (Allen et al. 2019). Third, soil water supply in pre-growing-season (winter snow, spring precipitation, and frozen soil) is playing an increasingly important role in regulating tree growth in many temperate regions (Eamus et al. 2013; Sugimoto et al. 2003; Wu et al. 2019; Allen et al. 2019). Our findings clearly highlight that the compensatory effect of winter snow could contribute more significantly to larch growth in years with drier climate conditions (Fig. 4).

\subsection{Compensation effect of winter snow}

Our findings indicate that winter snow exerts spatially divergent compensation effect on the subsequent growing-season tree growth for larch forests across a drought gradient, and this compensation effect is more evident in sites with higher winter snow. Previous findings indicate that the magnitude of the lagged snow effect depends on the proportion of winter 
snow to pre-growing-season precipitation (Wu et al. 2019). In our study, the generally low proportion of winter snow to pre-growing-season precipitation in dry sites of WLB and BRG $(\sim 8 \%)$ seemed to explain the non-significant role of winter snow on tree growth at these sites; however, much deeper winter snow indeed led to a high compensation effect on tree growth in snow rich sites (Fig. S5). Winter snow can significantly influence soil water during the growing season through the snowmelt water supply (Potopova et al. 2016; Allen et al. 2019; Shamir et al. 2020). In our study region, leaf-out of larch trees normally begins in late April, followed by xylem formation (Quan and Wang 2018). In snow-rich regions of Northeast China, snow is present in April but has mostly disappeared by May, and a previous study found that mean snow cover fraction from 1987 to 2014 was $23 \%$ in April compared to $0 \%$ in May (Zhang et al. 2018). Therefore, the presence of snow cover in April gave trees access to pre-monsoon water supply when the growing season generally commenced in late April. Our findings confirmed that in snow-rich sites (i.e., WEG and GH), there was a high (with relative contribution of 24.4-48.0\%) compensation effect of winter snow depth on subsequent growing-season tree growth (Fig. 4e and f).

Larch trees have a higher proportion of fine roots in shallow organic and mineral soil horizons (Iversen et al. 2018; Kajimoto et al. 2007; Zhang et al. 2018). The snow water mainly recharges the surface soil (Sugimoto et al. 2003) in such water-limited regions. Together with the thick humus layer in the larch forests, more snowmelt water could be kept in the soil to provide water supply in the subsequent growing season. The results of hydrogen and oxygen stable isotope analyses consistently indicated that larch trees mainly absorbed shallow soil water in the early growing season. In addition, the insulation effects of winter snow may also facilitate tree growth in the subsequent growing season. It is well documented that increased depth and duration of soil freezing caused by snowpack reductions adversely impact fine root dynamics (Reinmann and Templer 2016), shoot elongation (Comerford et al. 2013), and N uptake and $\mathrm{N}$ retention by northern forests (Campbell et al. 2014).

However, with rapid climate warming, particularly during winter and spring, there tends to be earlier snow melting and increase in evapotranspiration into the atmosphere, which thus reduces soil moisture availability in semi-arid regions, further constraining forest growth (Pederson et al. 2011; Peng et al. 2013; Liu et al. 2013; Tan et al. 2019). More importantly, our results indicate that the compensation effect of winter snow on tree growth is particularly important in drier years, highlighting the crucial role of winter snow in sustaining forest growth in a drying climate. Forests exhibit a drought legacy response with reduced growth during up to 4 years after an extreme drought (Wu et al. 2018b; Anderegg et al. 2015). Trees could make better use of the winter soil moisture storage which buffer them from severe drought stress and growth depressions in a subsequent drought during the growing season (Scharnweber et al. 2020). We reasonably hypothesized that the compensation effect of winter snow could play an important role in alleviating drought stress for post-drought forest recovery, nevertheless, such processes remain poorly understood.

Previous findings have implied that forest growth across temperate China has already suffered from progressively stronger drought limitations during the past decades, particularly in semi-arid regions (Liu et al. 2013; Wu et al. 2018b). We further found that larch growth in Northeast China has become more limited by drought stress in recent decades, and water availability from winter snow and spring precipitation may play an increasingly important role in regulating subsequent larch growth. These findings provide valuable insights into the regional larch forest dynamics in facing a warmer and drier climate and should be useful for devising adaptive larch forest management strategies in Northeast China. 


\section{Conclusions}

Our findings from a drought gradient indicate that the larch forests distributed over temperate China are becoming increasingly vulnerable to intensifying drought, and tree growth is becoming temporally more variable. We revealed a clear compensation effect of winter snow on subsequently growing-season tree growth in snow-rich regions, but not in snow-poor and semi-arid regions. Interestingly, such compensation effect of winter snow on subsequent growing-season tree growth is becoming more prominent in dry than in wet years, implying a crucial role of winter snow in maintaining tree growth under drought events. Given a continuous increase in both the severity and duration of drought that is reasonably projected to accompany rapid climate warming in the majority of midlatitude temperate regions, the compensation effect of winter snow may play a vital role in the resistance and resilience of these forests in facing a hotter and drier future climate in these areas.

Supplementary Information The online version contains supplementary material available at https://doi.org/ 10.1007/s10584-021-02998-1.

Acknowledgments This work was financially supported by the National Natural Science Foundation of China (NSFC 41922001, 41571038, 41530747, and 41390462), the National Key Research and Development Program of the Ministry of Science and Technology of China (No. 2016YFD060020603), and the State Key Laboratory of Land Surface Processes and Resource Ecology (grant No. 2017-ZY-06).

\section{Compliance with ethical standards}

Conflict of interest All authors declare that there are no conflicts of interest.

Open Access This article is licensed under a Creative Commons Attribution 4.0 International License, which permits use, sharing, adaptation, distribution and reproduction in any medium or format, as long as you give appropriate credit to the original author(s) and the source, provide a link to the Creative Commons licence, and indicate if changes were made. The images or other third party material in this article are included in the article's Creative Commons licence, unless indicated otherwise in a credit line to the material. If material is not included in the article's Creative Commons licence and your intended use is not permitted by statutory regulation or exceeds the permitted use, you will need to obtain permission directly from the copyright holder. To view a copy of this licence, visit http://creativecommons.org/licenses/by/4.0/.

\section{References}

Allen CD et al (2010) A global overview of drought and heat-induced tree mortality reveals emerging climate change risks for forests. For Ecol Manag 259(4):660-684. https://doi.org/10.1016/j.foreco.2009.09.001

Allen CD, Breshears DD, McDowell NG (2015) On underestimation of global vulnerability to tree mortality and forest die-off from hotter drought in the Anthropocene. Ecosphere 6(8):129. https://doi.org/10.1890/Es1500203.1

Allen ST, Kirchner JW, Braun S, Siegwolf RTW, Goldsmith GR (2019) Seasonal origins of soil water used by trees. Hydrol Earth Syst Sci 23(2):1199-1210. https://doi.org/10.5194/hess-23-1199-2019

Anderegg WRL et al (2015) Pervasive drought legacies in forest ecosystems and their implications for carbon cycle models. Science 349(6247):528-532. https://doi.org/10.1126/science.aab1833

Anderegg WRL et al (2020) Climate-driven risks to the climate mitigation potential of forests. Science 368(6497):1327. https://doi.org/10.1126/science.aaz7005 
Barnett TP, Adam JC, Lettenmaier DP (2005) Potential impacts of a warming climate on water availability in snow-dominated regions. Nature 438(7066):303-309. https://doi.org/10.1038/nature04141

Bhusal N, Lee M, Han AR, Han A, Kim HS (2020) Responses to drought stress in Prunus sargentii and Larix kaempferi seedlings using morphological and physiological parameters. For Ecol Manag 465:118099. https://doi.org/10.1016/J.Foreco.2020.118099

Blume-Werry G, Kreyling J, Laudon H, Milbau A (2016) Short-term climate change manipulation effects do not scale up to long-term legacies: effects of an absent snow cover on boreal forest plants. J Ecol 104(6):16381648. https://doi.org/10.1111/1365-2745.12636

Brodribb TJ, Powers J, Cochard H, Choat B (2020) Hanging by a thread? Forests and drought. Science 368(6488):261. https://doi.org/10.1126/science.aat7631

Campbell JL, Socci AM, Templer PH (2014) Increased nitrogen leaching following soil freezing is due to decreased root uptake in a northern hardwood forest. Glob Chang Biol 20(8):2663-2673. https://doi.org/10. $1111 /$ gcb.12532

Chakraborty D, Jandl R, Kapeller S, Schueler S (2019) Disentangling the role of climate and soil on tree growth and its interaction with seed origin. Sci Total Environ 654:393-401. https://doi.org/10.1016/j.scitotenv.2018. 11.093

Ciais P et al (2005) Europe-wide reduction in primary productivity caused by the heat and drought in 2003. Nature 437(7058):529-533. https://doi.org/10.1038/nature03972

Comerford DP et al (2013) Influence of experimental snow removal on root and canopy physiology of sugar maple trees in a northern hardwood forest. Oecologia 171(1):261-269. https://doi.org/10.1007/s00442-0122393-x

Cook ER, Kairiukstis LA (1990) Methods of dendrochronology, applications in the environmental sciences. Kluwer Academic Publishers, Boston

Dai AG (2013) Increasing drought under global warming in observations and models. Nat Clim Chang 3(1):5258. https://doi.org/10.1038/Nclimate1633

Davis EL, Gedalof Z (2018) Limited prospects for future alpine treeline advance in the Canadian Rocky Mountains. Glob Chang Biol 24(10):4489-4504. https://doi.org/10.1111/gcb.14338

Dulamsuren C, Hauck M, Khishigjargal M, Leuschner HH, Leuschner C (2010) Diverging climate trends in Mongolian taiga forests influence growth and regeneration of Larix sibirica. Oecologia 163(4):1091-1102. https://doi.org/10.1007/s00442-010-1689-y

Dulamsuren C, Hauck M, Leuschner HH, Leuschner C (2011) Climate response of tree-ring width in Larix sibirica growing in the drought-stressed forest-steppe ecotone of northern Mongolia. Ann For Sci 68(2):275282. https://doi.org/10.1007/s13595-011-0043-9

Eamus D, Boulain N, Cleverly J, Breshears DD (2013) Global change-type drought-induced tree mortality: vapor pressure deficit is more important than temperature perse in causing decline in tree health. Ecol Evol 3(8): 2711-2729. https://doi.org/10.1002/ece3.664

Ehleringer JR, Dawson TE (1992) Water-uptake by plants - perspectives from stable isotope composition. Plant Cell Environ 15(9):1073-1082. https://doi.org/10.1111/j.1365-3040.1992.tb01657.x

Ellsworth PZ, Sternberg LSL (2015) Seasonal water use by deciduous and evergreen woody species in a scrub community is based on water availability and root distribution. Ecohydrology 8(4):538-551. https://doi.org/ $10.1002 /$ eco. 1523

Fang OY, Zhang QB (2019) Tree resilience to drought increases in the Tibetan plateau. Glob Chang Biol 25(1): 245-253. https://doi.org/10.1111/gcb.14470

Grippa $\mathrm{M}$ et al (2005) The impact of snow depth and snowmelt on the vegetation variability over central Siberia. Geophys Res Lett 32(21):L21412. https://doi.org/10.1029/2005g1024286

Grossiord C et al (2020) Plant responses to rising vapor pressure deficit. New Phytol 226(6):1550-1566. https:// doi.org/10.1111/nph.16485

Hamlet AF, Mote PW, Clark MP, Lettenmaier DP (2005) Effects of temperature and precipitation variability on snowpack trends in the western United States. J Clim 18(21):4545-4561. https://doi.org/10.1175/Jcli3538.1

Holmes RL (1983) Computer-assisted quality control in tree-ring dating and measurement. Tree-Ring Bull 43 : $69-78$

Huang MT, Wang XH, Keenan TF, Piao SL (2018) Drought timing influences the legacy of tree growth recovery. Glob Chang Biol 24(8):3546-3559. https://doi.org/10.1111/gcb.14294

IPCC (2013) Climate change 2013 - the physical science basis, working group I contribution to the fifth assessment report of the intergovernmental panel on climate change. Cambridge University Press, Cambridge

Iversen CM et al (2018) Fine-root growth in a forested bog is seasonally dynamic, but shallowly distributed in nutrient-poor peat. Plant Soil 424(1-2):123-143. https://doi.org/10.1007/s11104-017-3231-z

Jin HJ et al (2007) Degradation of permafrost in the Xing'anling mountains, northeastern China. Permafr Periglac Process 18(3):245-258. https://doi.org/10.1002/ppp.589 
Kajimoto T et al (2007) Individual-based measurement and analysis of root system development: case studies for Larix gmelinii trees growing on the permafrost region in Siberia. J Forest Res Jpn 12(2):103-112. https://doi. org/10.1007/s10310-006-0259-y

Kunz J, Loffler G, Bauhus J (2018) Minor European broadleaved tree species are more drought-tolerant than Fagus sylvatica but not more tolerant than Quercus petraea. For Ecol Manag 414:15-27. https://doi.org/10. 1016/j.foreco.2018.02.016

Ladwig LM et al (2016) Beyond arctic and alpine: the influence of winter climate on temperate ecosystems. Ecology 97(2):372-382. https://doi.org/10.1890/15-0153.1

Liu HY et al (2013) Rapid warming accelerates tree growth decline in semi-arid forests of inner Asia. Glob Chang Biol 19(8):2500-2510. https://doi.org/10.1111/gcb.12217

Lopatin J, Dolos K, Hernandez HJ, Galleguillos M, Fassnacht FE (2016) Comparing generalized linear models and random forest to model vascular plant species richness using LiDAR data in a natural forest in Central Chile. Remote Sens Environ 173:200-210. https://doi.org/10.1016/j.rse.2015.11.029

Lyu SN, Wang XC, Zhang YD, Li ZS (2017) Different responses of Korean pine (Pinus koraiensis) and Mongolia oak (Quercus mongolica) growth to recent climate warming in Northeast China. Dendrochronologia 45:113-122. https://doi.org/10.1016/j.dendro.2017.08.002

Martin J, Looker N, Hoylman Z, Jencso K, Hu J (2018) Differential use of winter precipitation by upper and lower elevation Douglas fir in the northern Rockies. Glob Chang Biol 24(12):5607-5621. https://doi.org/10. $1111 /$ gcb. 14435

Mccullagh P (1984) Generalized linear-models. Eur J Oper Res 16(3):285-292. https://doi.org/10.1016/03772217(84)90282-0

Mcllroy SK, Shinneman DJ (2020) Post-fire aspen (Populus tremuloides) regeneration varies in response to winter precipitation across a regional climate gradient. For Ecol Manag 455:117681. https://doi.org/10.1016/ J.Foreco.2019.117681

Pederson GT et al (2011) The unusual nature of recent snowpack declines in the North American cordillera. Science 333(6040):332-335. https://doi.org/10.1126/science.1201570

Pederson $\mathrm{N}$ et al (2012) Long-term drought sensitivity of trees in second-growth forests in a humid region. Can J For Res 42(10):1837-1850. https://doi.org/10.1139/x2012-130

Peng SS, Piao SL, Ciais P, Fang JY, Wang XH (2010) Change in winter snow depth and its impacts on vegetation in China. Glob Chang Biol 16(11):3004-3013. https://doi.org/10.1111/j.1365-2486.2010.02210. $\mathrm{X}$

Peng SS et al (2013) Change in snow phenology and its potential feedback to temperature in the northern hemisphere over the last three decades. Environ Res Lett 8(1):014008. https://doi.org/10.1088/1748-9326/8/ $1 / 014008$

Potopova V, Boroneant C, Mozny M, Soukup J (2016) Driving role of snow cover on soil moisture and drought development during the growing season in the Czech Republic. Int J Climatol 36(11):3741-3758. https://doi. org/10.1002/joc. 4588

Quan XK, Wang CK (2018) Acclimation and adaptation of leaf photosynthesis, respiration and phenology to climate change: a 30-year Larix gmelinii common-garden experiment. For Ecol Manag 411:166-175. https:// doi.org/10.1016/j.foreco.2018.01.024

Rehschuh R, Mette T, Menzel A, Buras A (2017) Soil properties affect the drought susceptibility of Norway spruce. Dendrochronologia 45:81-89. https://doi.org/10.1016/j.dendro.2017.07.003

Reinmann AB, Templer PH (2016) Reduced winter snowpack and greater soil frost reduce live root biomass and stimulate radial growth and stem respiration of red maple (Acer rubrum) trees in a mixed-hardwood forest. Ecosystems 19(1):129-141. https://doi.org/10.1007/s10021-015-9923-4

Reinmann AB, Templer PH (2018) Increased soil respiration in response to experimentally reduced snow cover and increased soil freezing in a temperate deciduous forest. Biogeochemistry 140(3):359-371. https://doi. org/10.1007/s10533-018-0497-z

Reinmann AB, Susser JR, Demaria EMC, Templer PH (2019) Declines in northern forest tree growth following snowpack decline and soil freezing. Glob Chang Biol 25(2):420-430. https://doi.org/10.1111/gcb.14420

Ren P, Rossi S, Gricar J, Liang EY, Cufar K (2015) Is precipitation a trigger for the onset of xylogenesis in Juniperus przewalskii on the north-eastern Tibetan Plateau? Ann Bot 115(4):629-639. https://doi.org/10. 1093/aob/mcu259

Ren P et al (2018) Critical temperature and precipitation thresholds for the onset of xylogenesis of Juniperus przewalskii in a semi-arid area of the north-eastern Tibetan Plateau. Ann Bot 121(4):617-624. https://doi. org/10.1093/aob/mcx 188

Rotenberg E, Yakir D (2010) Contribution of semi-arid forests to the climate system. Science 327(5964):451454. https://doi.org/10.1126/science. 1179998

Rotenberg E, Yakir D (2011) Distinct patterns of changes in surface energy budget associated with forestation in the semiarid region. Glob Chang Biol 17(4):1536-1548. https://doi.org/10.1111/j.1365-2486.2010.02320.x 
Rothfuss Y, Javaux M (2017) Reviews and syntheses: isotopic approaches to quantify root water uptake: a review and comparison of methods. Biogeosciences 14(8):2199-2224. https://doi.org/10.5194/bg-14-21992017

Rowland L et al (2015) Death from drought in tropical forests is triggered by hydraulics not carbon starvation. Nature 528(7580):119. https://doi.org/10.1038/nature15539

Scharnweber T, Smiljanic M, Cruz-Garcia R, Manthey M, Wilmking M (2020) Tree growth at the end of the 21st century-the extreme years 2018/19 as template for future growth conditions. Environ Res Lett 15(7):074022. https://doi.org/10.1088/1748-9326/Ab865d

Shamir E et al (2020) Snowpack - and soil water content-related hydrologic indices and their association with radial growth of conifers in the Sierra Nevada, California. J Geophys Res Biogeosci 125(1):e2019JG005331. https://doi.org/10.1029/2019JG005331

Shen CC, Wang L, Li MY (2016) The altitudinal variability and temporal instability of the climate-tree-ring growth relationships for Changbai larch (Larix olgensis Henry) in the Changbai mountains area, Jilin, Northeastern China. Trees Struct Funct 30(3):901-912. https://doi.org/10.1007/s00468-015-1330-0

Shi FZ et al (2019) Seasonal divergent tree growth trends and growth variability along drought gradient over northeastern China. Forests 10(1):39. https://doi.org/10.3390/F10010039

Sugimoto A et al (2003) Characteristics of soil moisture in permafrost observed in East Siberian taiga with stable isotopes of water. Hydrol Process 17(6):1073-1092. https://doi.org/10.1002/hyp.1180

Takala $\mathrm{M}$ et al (2011) Estimating northern hemisphere snow water equivalent for climate research through assimilation of space-borne radiometer data and ground-based measurements. Remote Sens Environ 115(12):3517-3529. https://doi.org/10.1016/j.rse.2011.08.014

Tan XJ et al (2019) Spatiotemporal changes in snow cover over China during 1960-2013. Atmos Res 218:183194. https://doi.org/10.1016/j.atmosres.2018.11.018

Trahan MW, Schubert BA (2016) Temperature-induced water stress in high-latitude forests in response to natural and anthropogenic warming. Glob Chang Biol 22(2):782-791. https://doi.org/10.1111/gcb.13121

Trumbore S, Brando P, Hartmann H (2015) Forest health and global change. Science 349(6250):814-818. https://doi.org/10.1126/science.aac6759

van Der Schrier G et al (2013) A scPDSI-based global data set of dry and wet spells for 1901-2009. J Geophys Res Atmos 118:4025-4048. https://doi.org/10.1002/jgrd.50355

Vicente-Serrano SM, Camarero JJ, Azorin-Molina C (2014) Diverse responses of forest growth to drought timescales in the northern hemisphere. Glob Ecol Biogeogr 23(9):1019-1030. https://doi.org/10.1111/geb.12183

Wang XC et al (2017) Temperature signals in tree-ring width and divergent growth of Korean pine response to recent climate warming in northeast Asia. Trees Struct Funct 31(2):415-427. https://doi.org/10.1007/ s00468-015-1341-X

Wang XY et al (2018) Disentangling the mechanisms behind winter snow impact on vegetation activity in northern ecosystems. Glob Chang Biol 24(4):1651-1662. https://doi.org/10.1111/gcb.13930

Wells N, Goddard S, Hayes MJ (2004) A self-calibrating palmer drought severity index. J Clim 17(12):23352351. https://doi.org/10.1175/1520-0442(2004)017<2335:Aspdsi $>2.0 . C 0 ; 2$

West AG, Patrickson SJ, Ehleringer JR (2006) Water extraction times for plant and soil materials used in stable isotope analysis. Rapid Commun Mass Spectrom 20(8):1317-1321. https://doi.org/10.1002/rcm.2456

Wipf S, Rixen C (2010) A review of snow manipulation experiments in Arctic and alpine tundra ecosystems. Polar Res 29(1):95-109. https://doi.org/10.1111/j.1751-8369.2010.00153.x

Wipf S, Stoeckli V, Bebi P (2009) Winter climate change in alpine tundra: plant responses to changes in snow depth and snowmelt timing. Clim Chang 94(1-2):105-121. https://doi.org/10.1007/s10584-009-9546-x

Wu QQ (2018) Effects of snow depth manipulation on the releases of carbon, nitrogen and phosphorus from the foliar litter of two temperate tree species. Sci Total Environ 643:1357-1365. https://doi.org/10.1016/j. scitotenv.2018.06.308

$\mathrm{Wu} \mathrm{X}$ et al (2012a) Growth decline linked to warming-induced water limitation in hemi-boreal forests. PLoS One 7(8):e42619. https://doi.org/10.1371/journal.pone.0042619

Wu HW et al (2018a) Determining root water uptake of two alpine crops in a rainfed cropland in the Qinghai Lake watershed: first assessment using stable isotopes analysis. Field Crop Res 215:113-121. https://doi.org/ 10.1016/j.fcr.2017.10.011

Wu XC et al (2018b) Differentiating drought legacy effects on vegetation growth over the temperate northern hemisphere. Glob Chang Biol 24(1):504-516. https://doi.org/10.1111/gcb.13920

$\mathrm{Wu} \mathrm{XC}$ et al (2019) Uneven winter snow influence on tree growth across temperate China. Glob Chang Biol 25(1):144-154. https://doi.org/10.1111/gcb.14464

Zhang RB et al (2016a) Tree-ring-based moisture variability in western Tianshan Mountains since AD 1882 and its possible driving mechanism. Agric For Meteorol 218:267-276. https://doi.org/10.1016/j.agrformet.2015. 12.067 
Zhang XL, Bai XP, Chang YX, Chen ZJ (2016b) Increased sensitivity of Dahurian larch radial growth to summer temperature with the rapid warming in Northeast China. Trees Struct Funct 30(5):1799-1806. https://doi. org/10.1007/s00468-016-1413-6

Zhang RB et al (2017) Tree-ring-based precipitation reconstruction in southern Kazakhstan, reveals drought variability since AD 1770. Int J Climatol 37(2):741-750. https://doi.org/10.1002/joc.4736

Zhang YP, Jiang Y, Wang B, Jiao L, Wang MC (2018) Seasonal water use by Larix principis-rupprechtii in an alpine habitat. For Ecol Manag 409:47-55. https://doi.org/10.1016/j.foreco.2017.11.009

Zhang XL et al (2019b) Snowmelt and early to mid-growing season water availability augment tree growth during rapid warming in southern Asian boreal forests. Glob Chang Biol 25(10):3462-3471. https://doi.org/ $10.1111 / \mathrm{gcb} .14749$

Zhu LJ, Cooper DJ, Yang JW, Zhang X, Wang XC (2018) Rapid warming induces the contrasting growth of Yezo spruce (Picea jezoensis var. microsperma) at two elevation gradient sites of northeast China. Dendrochronologia 50:52-63. https://doi.org/10.1016/j.dendro.2018.05.002

Publisher's note Springer Nature remains neutral with regard to jurisdictional claims in published maps and institutional affiliations. 